\title{
Residual Oil Cracking with Hydrogen Generation
}

\author{
Teruo Suzuka \\ Central Research Laboratories, Nippon Mining Co., Ltd., \\ 3-17-35, Niizo-Minami, Toda-shi, Saitama 335
}

(Received April 4, 1986)

\begin{abstract}
The cracking of residual oils with simultaneous hydrogen generation has been carried out. In this process, the by-product coke deposited on the surface of the catalyst is partially oxidized in the regenerator with the formation of carbon monoxide, and the heat of reaction generated is utilized for cracking of the feed. Carbon monoxide works as a reducing agent for converting triiron tetraoxide $\left(\mathrm{Fe}_{3} \mathrm{O}_{4}\right)$ in the catalyst to ferrous oxide $(\mathrm{FeO})$, which in turn, is converted to $\mathrm{Fe}_{3} \mathrm{O}_{4}$ by its reacting with steam to generate hydrogen. A large amount of hydrogen can be produced from the process without coke formation. The amount of hydrogen production is large enough to desulfurize the product distillates produced from the process. Feasibility of the process for upgrading residual oils has been confirmed by the results of 0.6 BPD- and 250 BPD- pilot plants.
\end{abstract}

\section{Introduction}

It is difficult to predict the future of the petroleum refining industry under the current unstable circumstances. However, the fact must be recognized that demands for lighter products are increasing and that crude oils are getting heavier. Such circumstances will obviously bring about a glut of residual oils, which need to be converted into lighter, more valuable products at reasonable costs. Efforts are being made to meet the need.

This paper discusses the cracking of residual oils with simultaneous hydrogen generation. The basic research on the process was carried out by Nippon Mining Co. and the process further developed jointly by researchers from Nippon Mining Co., Hitachi Ltd., and Kashima Oil Co. serving as members of the Research Association for Residual Oil Processing (RAROP).

\section{Cracking of Residual Oils over an Iron Catalyst}

Iron is a well known catalyst for hydrocarbon dehydrogenation, ${ }^{1)}$ carbon gasification, ${ }^{2)}$ coal liquefaction, ${ }^{3)}$ the Fischer-Tropsch reaction, ${ }^{4)}$ ammonia synthesis, ${ }^{5)}$ and others. ${ }^{6}$ ) In these reactions, iron acts mainly as a dehydrogenation catalyst or a redox agent.

Cracking of residual oils over nickel oxide ore has been studied, and the ore was found to be an effective catalyst. ${ }^{7) ~ 10) ~ A ~ l o w e r ~ y i e l d ~ o f ~ h e a v y ~ f r a c-~}$ tion boiling at temperatures above $343^{\circ} \mathrm{C}$ and a higher coke yield were obtained over laterite catalyst $\mathrm{A}$ in comparison with other catalysts, ${ }^{11)}$ though iron oxide ore showed low activity for cracking of residual oils. ${ }^{12), 13)}$ This is probably because laterite A not only contains a large amount of nickel and iron, both of which accelerate dehydrogenation and coke formation, but it also has a larger specific surface area than other catalysts. Table 1 lists the properties of laterite catalysts.

Laterite is a red soil of weathered rock and is widely distributed in the tropical and subtropical zones. The supply of laterite is said to be inexhaustible, and it can probably be used in the future. From the viewpoint of commercialization, it has the advantage of yielding smaller amounts of heavy fractions because of the lower amount of recycle oil involved. Although high coke production that results in lower oil yields is generally considered a disadvantage, high coke production can be utilized for high hydrogen generation in the process combining residual oil cracking and hydrogen generation. This process will be discussed subsequently. The mechanical strength of a catalyst is one of the important characteristics when the catalyst is used in fluidized bed reactors. The higher the calcination temperature, the higher the attrition resistance of the catalyst. Effects of calcination temperature of nickel oxide ore on cracking of residual oils and on mechanical strengths were reported. ${ }^{14}$ ) In some experiments, laterite was calcined at 1,100-1,200 ${ }^{\circ} \mathrm{C}$ though its activity approached that of thermal cracking at such high temperatures. 
Table 1 Composition and Properties of Catalysts

\begin{tabular}{|c|c|c|c|c|c|c|}
\hline & $\begin{array}{c}\mathrm{Fe} \\
(w \mathrm{wt} \%)\end{array}$ & $\underset{(\mathrm{wt} \%)}{\mathrm{Ni}}$ & $\underset{(\mathrm{wt} \%)}{\mathrm{MgO}}$ & $\begin{array}{c}\mathrm{SiO}_{2} \\
(\mathrm{wt} \%)\end{array}$ & $\begin{array}{c}\mathrm{Al}_{2} \mathrm{O}_{3} \\
(\mathrm{wt} \%)\end{array}$ & $\begin{array}{c}\left.\text { S.A. }{ }^{a}\right) \\
\left(\mathrm{m}^{2} / \mathrm{g}\right)\end{array}$ \\
\hline $\begin{array}{ll}\text { Laterite catalyst } & \text { A } \\
\text { Laterite catalyst } & \text { B } \\
\text { Laterite catalyst } & \text { G } \\
\text { Laterite catalyst } & \text { D }\end{array}$ & $\begin{array}{l}57.9 \\
56.6 \\
50.2 \\
44.2\end{array}$ & $\begin{array}{l}1.23 \\
1.16 \\
1.1 \\
1.89\end{array}$ & $\begin{array}{l}0.76 \\
0.88 \\
0.5 \\
7.5\end{array}$ & $\begin{array}{l}2.44 \\
2.77 \\
1.8 \\
10.0\end{array}$ & $\begin{array}{l}2.83 \\
6.74 \\
2.4 \\
5.7\end{array}$ & $\begin{array}{r}10.6 \\
2.0 \\
0.5 \\
0.3\end{array}$ \\
\hline
\end{tabular}

a) Specific surface area

Changes in the properties and yields of recycle oil through a series of repeated cracking over laterite catalyst $B$ have been studied. ${ }^{15}$ ) Most of the heavy metals and asphalten decreased in the first repeated crackings of the series, and the amount of cracked products decreased with repetition due to the increase in the aromaticity of the recycle oil.

\section{Hydrogen Generation by the Reaction of Reduced Iron Oxide with Steam}

Regeneration efficiency is also one of the important characteristics of a catalyst in cracking. The combustion rate of coke on the laterite catalyst A was investigated in a fixed bed reactor, and, as shown in Fig. 1, most of the coke on the catalyst was consumed during heating of the catalyst bed in a flow of nitrogen gas prior to the introduction of combustion air. For comparison, the combustion curve of fluid coke is shown in dashes in Fig. 1. The iron oxide in the laterite catalyst seemed to be readily reducible by coke.

When coke-deposited laterite catalyst $\mathrm{C}$ was subjected to reduction, the percent reduction of iron oxide was found to increase with increasing amount of coke on the catalyst, as shown in Fig. 2. Results of X-ray diffraction for laterite catalyst $\mathrm{C}$ and those of gas analysis show that iron oxide in the catalyst is reduced to liberate carbon monoxide and dioxide. ${ }^{16)}$ The percent reduction of the catalyst streaming out of the regenerator was calculated from the following equation:

$$
\begin{aligned}
& R(\%)=\Delta R+R\left(\mathrm{Fe}_{3} \mathrm{O}_{4}\right) \\
& \Delta R(\%)=\frac{[\mathrm{CO}]+2\left[\mathrm{CO}_{2}\right]+2\left\{\left[\mathrm{O}_{2}\right]_{\text {out }}-\left[\mathrm{O}_{2}\right]_{\mathrm{in}}\right\}}{1.5 \mathrm{~N}_{\mathrm{Fe}}} \times 100
\end{aligned}
$$

where $R$ : percent reduction of the catalyst $(R=0$ for $\mathrm{Fe}_{2} \mathrm{O}_{3}$ and $R=100$ for $\mathrm{Fe}$ ),

$$
R\left(\mathrm{Fe}_{3} \mathrm{O}_{4}\right) \text { : percent reduction of } \mathrm{Fe}_{3} \mathrm{O}_{4}=11.1
$$

$R$ : difference between percent reductions of the catalyst at the regenerator inlet and outlet, respectively,

[CO]: amount of $\mathrm{CO}$ in the regenerator outlet gas, (g-mol/hr)

$\left[\mathrm{CO}_{2}\right]$ : amount of $\mathrm{CO}_{2}$ in the regenerator outlet gas, $(\mathrm{g}-\mathrm{mol} / \mathrm{hr})$

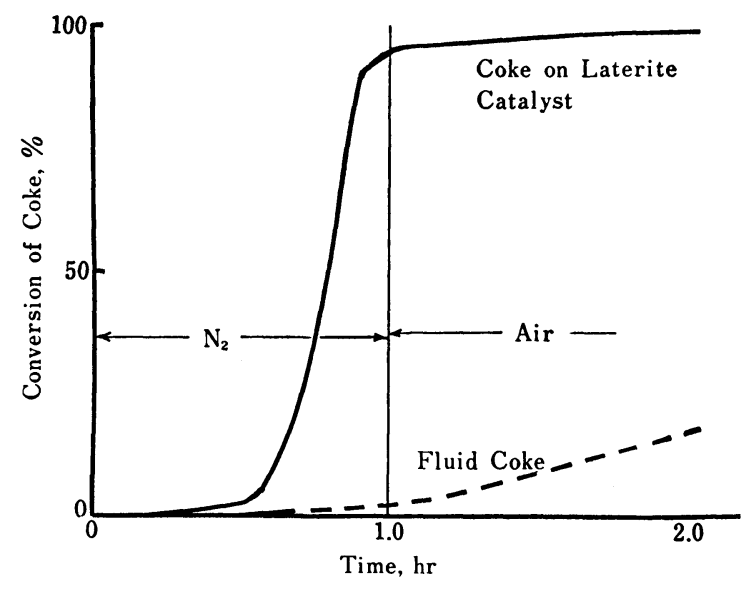

Fig. 1 Conversion of Coke on Laterite Catalyst

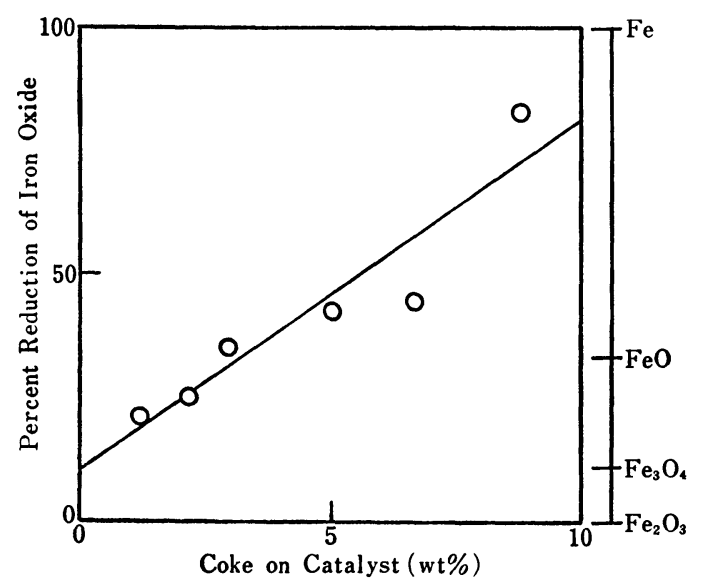

Fig. 2 Relationship between Amount of Coke on Catalyst and Percent Reduction of Iron Oxide

$\left[\mathrm{O}_{2}\right]_{\text {out }}$ : amount of $\mathrm{O}_{2}$ in the regenerator outlet gas, (g-mol/hr)

$\left[\mathrm{O}_{2}\right]_{\mathrm{in}}$ : amount of $\mathrm{O}_{2}$ in the regenerator inlet gas, $(\mathrm{g}-\mathrm{mol} / \mathrm{hr})$, and

$\mathrm{N}_{\mathrm{Fe}}$ : amount of iron in the catalyst fed to the regenerator, (g-mol/hr).

Hydrogen was generated by steam reacting with ferrous oxide produced by the reduction of the catalyst. As Fig. 3 shows, the amount of hydrogen increases with increasing percent reduction of the iron oxide.

Burning coke on the catalyst to supply the heat for residual oil cracking is necessary. Therefore, 




Fig. 3 Generated Hydrogen vs. Percent Reduction of Iron Oxide

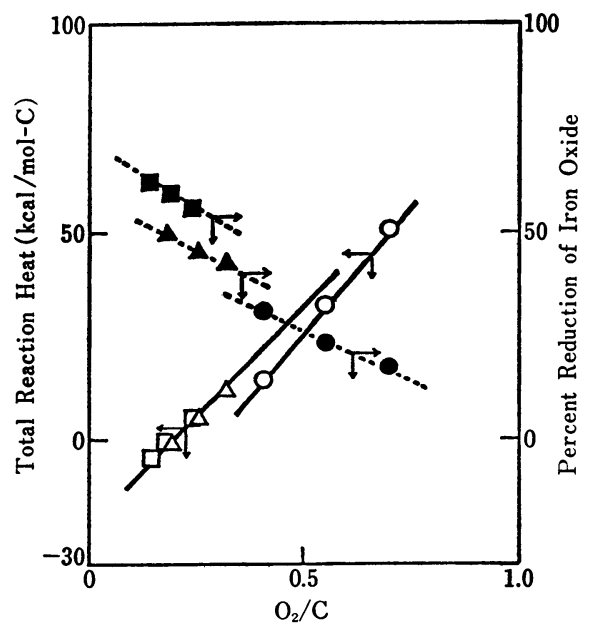

Coke on catalyst $(w t \%)-$

$\bigcirc, 0: 4.9, \Delta, \boldsymbol{\Delta}: 10.2, \square, \square: 12.8$

Fig. 4 Effect of $\mathrm{O}_{2} / \mathrm{C}$ on Total Reaction Heat and Percent Reduction of Iron Oxide

the conditions for heat generation by partial oxidation of coke and for reducing the iron oxide in the catalyst were investigated.

Major reactions at the partial oxidation stage were as follows:

$$
\begin{aligned}
& \mathrm{C}+\mathrm{O}_{2} \longrightarrow \mathrm{CO}_{2} \\
& \mathrm{C}+\mathrm{CO}_{2} \longrightarrow 2 \mathrm{CO} \\
& \mathrm{CO}+\mathrm{Fe}_{3} \mathrm{O}_{4} \longrightarrow \mathrm{CO}_{2}+3 \mathrm{FeO} \\
& \mathrm{CO}+\mathrm{FeO} \longrightarrow \mathrm{CO}_{2}+\mathrm{Fe}
\end{aligned}
$$

Figure 4 shows the relationship between the percent reduction of catalyst $\mathrm{C}$ and the ratio of oxygen in the inlet gas to carbon deposited on the catalyst $\left(\mathrm{O}_{2} / \mathrm{C}\right)$. The relationship between the total heat of reactions, $1-4$, and $\mathrm{O}_{2} / \mathrm{C}$ is also shown in Fig. 4. As this figure indicates, $\mathrm{O}_{2} / \mathrm{C}$ can regulate both the total heat of reaction and percent reduction of the catalyst. It was found using a fixed bed reactor that the higher the molar ratio of oxygen to carbon,

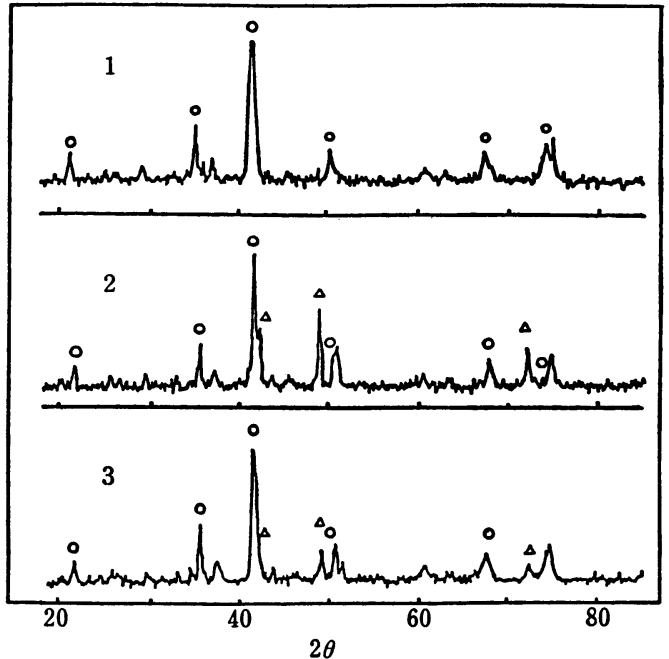

1: after cracking, 2: after regeneration, 3: after hydrogen generation

$\mathrm{O}: \mathrm{Fe}_{3} \mathrm{O}_{4}, \triangle: \mathrm{FeO}$

Fig. 5 X-ray Diffraction Patterns of the Catalyst at Various Reaction Stages

the lower the reduction of iron oxide, and the greater the heat evolved. The most favorable molar ratio appears to be $0.3-0.4$, because, in this range, the heat evolved in the regenerator corresponds to the heat required for cracking the residual oil.

\section{Reduction and Oxidation of Iron Oxide in a Fluidized Bed}

A coke-deposited catalyst was prepared by cracking Kuwait vacuum residual oil over laterite D. The iron oxide in the coke-deposited catalyst was reduced by partial oxidation of the coke. Hydrogen was generated by reaction of the reduced iron oxide with steam. These operations were carried out in fluidized bed reactors.

Figure 5 shows X-ray diffraction patterns of catalyst $\mathrm{C}$ at various reaction stages. The change in the crystal structure of the iron oxide is similar to that observed in the fixed bed reactor ${ }^{11)}$, that is, ferric oxide $\left(\mathrm{Fe}_{2} \mathrm{O}_{3}\right)$ changes to triiron tetraoxide $\left(\mathrm{Fe}_{3} \mathrm{O}_{4}\right)$ during cracking, and part of the triiron tetraoxide is reduced in the regenerator to ferrous oxide $(\mathrm{FeO})$ which is then oxidized to triiron tetraoxide in the hydrogen generator. As shown in Fig. 5, the crystal structure of the iron oxide changes between $\mathrm{FeO}$ and $\mathrm{Fe}_{3} \mathrm{O}_{4}$. In the steam-iron process developed at the Institute of Gas Technology (IGT), part of the iron oxide is reduced to metallic iron. ${ }^{17), 18)}$ However, sticking (or bogging) of the particles in the fluidized bed occurs more readily in this case ${ }^{19), 20)}$ although the amount of hydrogen 
generated by the reaction of metallic iron with steam is larger than that generated by the reaction of $\mathrm{FeO}$ with steam. Furthermore, the catalyst is assumed to be more easily pulverized because of the large difference in the specific volumes of $\mathrm{Fe}$ and $\mathrm{Fe}_{3} \mathrm{O}_{4} \cdot{ }^{21)}$

\section{Behavior of Sulfur ${ }^{22}$ )}

The behavior of sulfur in the process is assumed as shown in Fig. 6. In the cracker, most of the sulfur contained in the feed oil was transferred to the cracked oil $\left(560^{\circ} \mathrm{C}+\right)$ and coke. The sulfur content of the cracked oil $\left(560^{\circ} \mathrm{C}+\right)$ was almost the same as that of the feedstock.

The coke-deposited catalyst was charged continuously into the regenerator and then into the hydrogen generator. The concentration of sulfur in the gas from the regenerator was found to be so low that the gas emitted into the atmosphere will not cause serious air pollution problems, even without desulfurization. Concerning the composition of the sulfur compounds, it is considered that, when the sulfur in the coke is oxidized at the bottom of the regenerator, sulfur dioxide is first formed. Passing through the reactor in bubbles, the sulfur dioxide reacts with hydrogen or carbon monoxide to form hydrogen sulfide or carbonyl sulfide, respectively, which in turn reacts with iron oxide to form iron sulfide. ${ }^{23), 24)}$

$$
\begin{aligned}
& \text { Coke }+\mathrm{O}_{2} \longrightarrow \mathrm{CO}_{2}+\mathrm{SO}_{2}+\mathrm{H}_{2} \mathrm{O} \\
& \mathrm{CO}_{2}+\mathrm{C} \longrightarrow 2 \mathrm{CO} \\
& \mathrm{Fe}_{3} \mathrm{O}_{4}+\mathrm{CO} \longrightarrow 3 \mathrm{FeO}+\mathrm{CO}_{2} \\
& \mathrm{SO}_{2}+3 \mathrm{H}_{2} \longrightarrow \mathrm{H}_{2} \mathrm{~S}+2 \mathrm{H}_{2} \mathrm{O} \\
& \mathrm{SO}_{2}+3 \mathrm{CO} \longrightarrow \mathrm{COS}+2 \mathrm{CO}_{2} \\
& \mathrm{FeO}+\mathrm{H}_{2} \mathrm{~S} \longrightarrow \mathrm{FeS}+\mathrm{H}_{2} \mathrm{O} \\
& \mathrm{FeO}+\mathrm{COS} \longrightarrow \mathrm{FeS}+\mathrm{CO}_{2}
\end{aligned}
$$

The catalyst containing ferrous oxide $(\mathrm{FeO})$, triiron tetraoxide $\left(\mathrm{Fe}_{3} \mathrm{O}_{4}\right)$, iron sulfide $(\mathrm{FeS})$, and coke was charged to the hydrogen generator through the regenerator and reacted with steam at $750^{\circ} \mathrm{C}$ to generate hydrogen.

Iron sulfide is partially desulfurized by reacting with steam in the hydrogen generator. Desulfurization of iron sulfide is thought to be controlled by the equilibrium between the following reactions:25)

$$
\begin{aligned}
& 3 \mathrm{FeS}+4 \mathrm{H}_{2} \mathrm{O} \longrightarrow \mathrm{Fe}_{3} \mathrm{O}_{4}+3 \mathrm{H}_{2} \mathrm{~S}+\mathrm{H}_{2} \\
& \mathrm{C}+\mathrm{H}_{2} \mathrm{O} \longrightarrow \mathrm{H}_{2}+\mathrm{CO} \\
& \mathrm{CO}+\mathrm{H}_{2} \mathrm{O} \longrightarrow \mathrm{CO}_{2}+\mathrm{H}_{2}
\end{aligned}
$$

It is also evident from calculations that the more $\mathrm{FeO}$ is fed to the hydrogen generator, the lower becomes the precent desulfurization of $\mathrm{FeS}$.

\section{Process Involving Desulfurization of Iron Sulfide by Roasting}

When a sulfur-containing residual oil is cracked over a catalyst containing iron, and the coke on the catalyst is burned reductively, the iron oxide in the catalyst is sulfided into iron sulfide. This iron sulfide must be desulfurized if the catalyst is to be used repeatedly. One of the desulfurizing techniques is to react the iron sulfide with steam to remove the sulfur as hydrogen sulfide. Another technique is to roast the iron sulfide to remove the sulfur as sulfur dioxide. When a residual oil of such low sulfur content as Taching vacuum oil or desulfurized residual oil is used as feedstock, the iron sulfide is preferably desulfurized with steam, and the sulfur recovered as $\mathrm{H}_{2} \mathrm{~S}$. When a residual oil with a high sulfur content is used as feedstock, the sulfur will likely be accumulated in the catalyst if it is desulfurized with steam. In such a case, the removal of sulfur as $\mathrm{SO}_{2}$ by roasting the

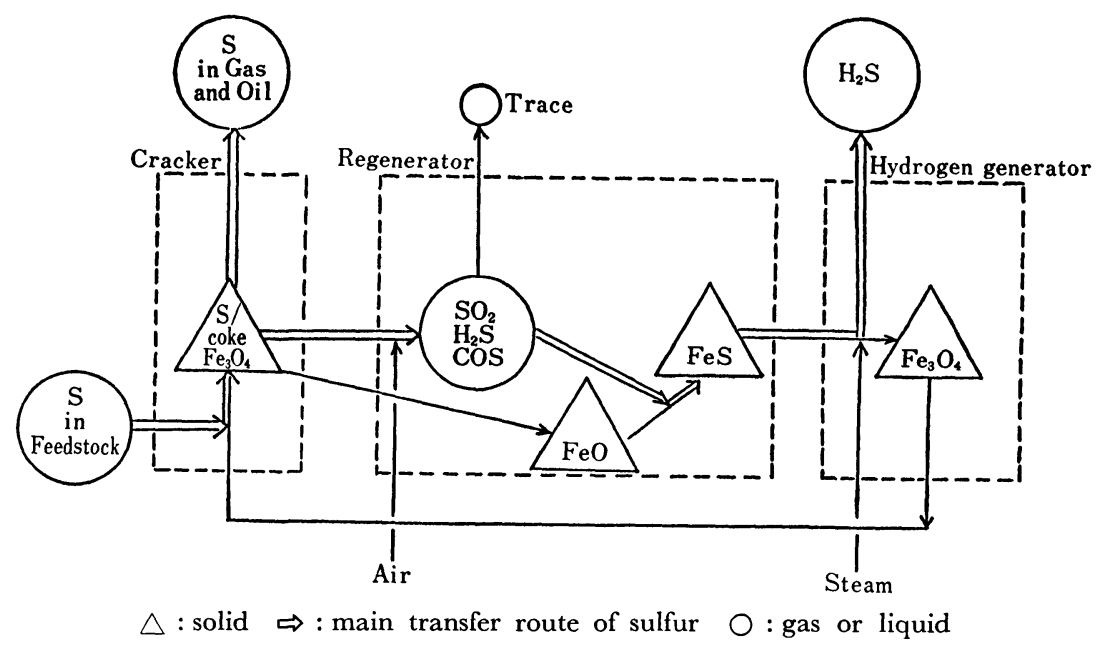

Fig. 6 Schematic Behavior of Sulfur 



Fig. 7 Hydrogen Concentration in Product Gas from Cracker, Amount of Hydrogen Generated, and $\mathrm{CO} / \mathrm{CO}_{2}$ Molar Ratio in Product Gas from Regenerator during 10-Day Run

iron sulfide is preferred. With the latter technique, the major reactions involved are as follows:

In the cracker:

$$
\begin{aligned}
& \begin{array}{l}
3 \mathrm{FeO}+\mathrm{H}_{2} \mathrm{O} \longrightarrow \mathrm{Fe}_{3} \mathrm{O}_{4}+\mathrm{H}_{2} \\
\mathrm{Fe}_{3} \mathrm{O}_{4}+\mathrm{Feed} \mathrm{oil} \longrightarrow \\
\text { Coke } / \mathrm{Fe}_{3} \mathrm{O}_{4}+\mathrm{Oil}+\mathrm{Gas}
\end{array}
\end{aligned}
$$

In the regenerator:

$$
\begin{aligned}
& \text { Coke } / \mathrm{Fe}_{3} \mathrm{O}_{4}+\mathrm{O}_{2} \longrightarrow \\
& \mathrm{Fe}_{3} \mathrm{O}_{4}+\mathrm{CO}+\mathrm{CO}_{2}+\mathrm{SO}_{2} \\
& \mathrm{Fe}_{3} \mathrm{O}_{4}+\mathrm{CO} \longrightarrow 3 \mathrm{FeO}+\mathrm{CO}_{2} \\
& \mathrm{FeO}+\mathrm{SO}_{2}+3 \mathrm{CO} \longrightarrow \mathrm{FeS}+3 \mathrm{CO}_{2}
\end{aligned}
$$

In the roaster:

$$
3 \mathrm{FeS}+5 \mathrm{O}_{2} \longrightarrow \mathrm{Fe}_{3} \mathrm{O}_{4}+3 \mathrm{SO}_{2}
$$

\section{Small Scale Pilot Plant Operation ${ }^{26), 27)}$}

Feasibility of our process for upgrading residual oils has been confirmed using a pilot plant of $4 \mathrm{~kg} / \mathrm{hr}$ (0.6 BPD) capacity. The cracker, the regenerator, and the roaster are made of type 304 stainless steel, and they are heated with electric furnaces. Sizes of the individual units are shown in Table 2. The composition and properties of the catalyst used are shown in Table 3.

Figure 7 shows the changes during a continuous

Table 2 Sizes and Operating Conditions of Pilot Plant

\begin{tabular}{l|ccc}
\hline & Cracker & $\begin{array}{c}\text { Regener- } \\
\text { ator }\end{array}$ & Roaster \\
\hline $\begin{array}{l}\text { Sizes: } \\
\text { Inner-diameter (mm) }\end{array}$ & 127 & 151 & 102 \\
$\begin{array}{l}\text { Height (mm) } \\
\text { Height of fluidized } \\
\quad \text { bed (mm) }\end{array}$ & 1,600 & 1,800 & 1,900 \\
$\begin{array}{l}\text { Operating conditions: } \\
\text { Reaction temperature } \\
\quad\left({ }^{\circ} \mathbf{C}\right) \text { ( }\end{array}$ & 500 & 500 & 600 \\
$\quad$ Fluidizing gas & $525-545$ & $780-830$ & $750-810$ \\
\hline
\end{tabular}

Table 3 Composition and Properties of Catalyst

\begin{tabular}{lrll}
\multicolumn{3}{c}{ Composition $(w \mathrm{wt} \%):$} \\
$\mathrm{Fe}_{2} \mathrm{O}_{3}$ & 82.1 & $\mathrm{SiO}_{2}$ & 2.7 \\
$\mathrm{NiO}$ & 1.5 & $\mathrm{Al}_{2} \mathrm{O}_{3}$ & 6.6 \\
$\mathrm{MgO}$ & 0.8 & \\
Properties: & & \\
Average particle diameter & $0.18 \mathrm{~mm}$ \\
Angle of repose & $35^{\circ}$ \\
Bulk density & $1.73 \mathrm{~g} / \mathrm{mL}$ \\
Specific surface area & $2 \mathrm{~m}^{2} / \mathrm{g}$ \\
\hline
\end{tabular}

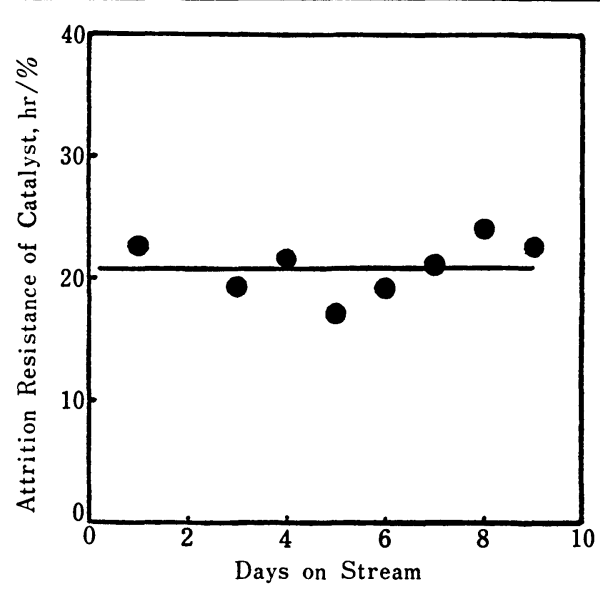

Fig. 8 Attrition Resistance of Catalyst vs. Days on Stream

ten-day run in the hydrogen concentration of the product gas from the cracker, in the amount of hydrogen generated, and in the $\mathrm{CO} / \mathrm{CO}_{2}$ molar ratio of the product gas from the regenerator. The higher the $\mathrm{CO} / \mathrm{CO}_{2}$ ratio was, the greater the amount of hydrogen generated. That is, increasing the reduction atmosphere inside the regenerator increased hydrogen generation, probably, because of the increased percent reduction of the catalyst. No catalyst deterioration was observed (Fig. 8) although the curve did fluctuate somewhat due to the 


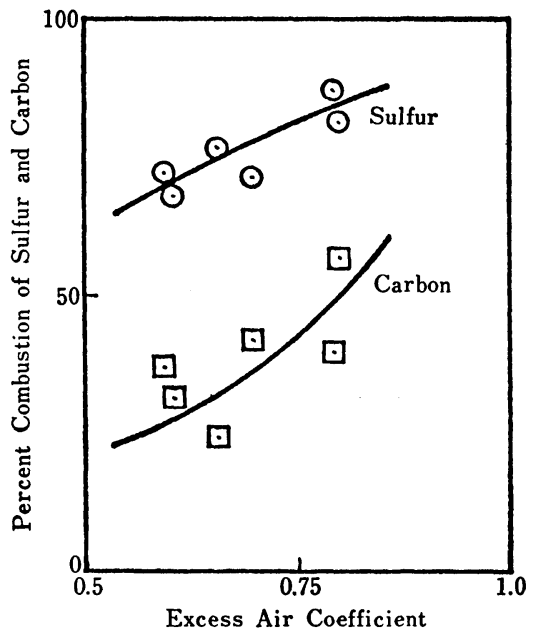

Fig. 9 Effect of Excess Air Coefficient on Percent Combustion of Sulfur and Carbon in Roaster of the Pilot Plant

varying operating conditions.

The amount of hydrogen generated was $180 \mathrm{Nl}-$ $\mathrm{H}_{2} / \mathrm{kg}$-feed oil by reacting ferrous oxide with steam and was $30 \mathrm{Nl}-\mathrm{H}_{2} / \mathrm{kg}$-feed oil by dehydrogenation of the feed oil.

Desulfurization of $\mathrm{FeS}$ was conducted, and the percent combustion of carbon was compared with the percent combustion of sulfur by varying the excess air coefficient at temperatures from 750 to $810^{\circ} \mathrm{C}$. Figure 9 shows the relationship between the excess air coefficient and the percent combustion of carbon and that of sulfur. Obviously, sulfur is more readily oxidized than carbon, especially at lower levels of excess air coefficient.

Roasting iron sulfide without coke is a wellknown process for sulfuric acid production. ${ }^{28) ~ 30)}$ In the present process, however, coke coexists with iron sulfide. It is preferable to minimize coke consumption during roasting because the coke acts as an effective reductant of iron oxide.

\section{Large Scale Pilot Plant Operation}

Commercial feasibility of this process was confirmed in 1983 by operating a large scale pilot plant (250 BPD) built in the Mizushima Refinery of Nippon Mining Company, Japan in 1981.

In fluidized bed engineering, bubbles in the fluidized bed grow with increasing reactor diameter, and their growth decreases contact efficiency. ${ }^{31}$ ) 33) Some efforts have been made to prevent the decrease in contact efficiency. ${ }^{34), 35)}$ In the scaling-up of a plant, it must be taken into account that the rate constant is reduced by decrease in contact efficiency between the reactant and catalyst particles

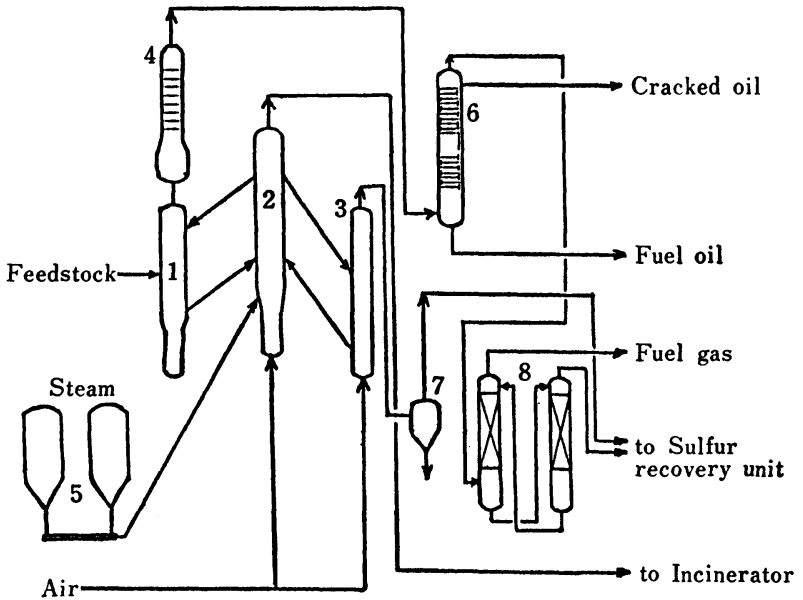

1. cracker, 2. regenerator, 3. roaster, 4. scrubber,

5. catalyst hopper, 6. fractionator, 7. cyclone,

8. $\mathrm{H}_{2} \mathrm{~S}$ absorption tower

Fig. 10 Flow Diagram of Large Scale Pilot Plant

Table 4 Sizes and Operating Conditions of Large Scale Pilot Plant

\begin{tabular}{|c|c|c|c|}
\hline & Cracker & $\begin{array}{l}\text { Regener- } \\
\text { ator }\end{array}$ & Roaster \\
\hline $\begin{array}{l}\text { Sizes: } \\
\text { Diameter (m) } \\
\text { Height (m) }\end{array}$ & $\begin{array}{l}0.82 \\
15.9\end{array}$ & $\begin{array}{l}1.60 \\
17.0\end{array}$ & $\begin{array}{l}0.56 \\
10.4\end{array}$ \\
\hline $\begin{array}{l}\text { Operating conditions: } \\
\text { Pressure }\left(\mathrm{kg} / \mathrm{cm}^{2}\right) \\
\text { Temperature }\left({ }^{\circ} \mathrm{G}\right) \\
\text { Feed rate (BPD) }\end{array}$ & $\begin{array}{l}2.3-3.5 \\
500-550 \\
150-250\end{array}$ & $\begin{array}{c}2.3-3.5 \\
780-850 \\
-\end{array}$ & $\begin{array}{c}2.3-3.5 \\
600-800 \\
-\end{array}$ \\
\hline
\end{tabular}

in the fluidized bed. ${ }^{36) \sim 38}$ )

Figure $\mathbf{1 0}$ is a process flow diagram of the plant. ${ }^{39)}$ Sizes and operating conditions of the individual units of the plant are shown in Table 4. ${ }^{40}$ The catalyst containing iron oxide was circulated between cracker and regenerator, and a small amount of the catalyst was circulated between regenerator and roaster to keep the sulfur content of the catalyst at a constant level.

At the beginning of the large-scale-pilot plant operation, large vertical forces in the fluidized bed were observed. These forces damaged the immersed tubes and their support system in the bed. The designer should be aware of the magnitude and frequency of the forces caused by buffeting action of bubbles, ${ }^{41), 42)}$ especially in the case of coarse particles with high specific gravity. ${ }^{43}$ These forces were eliminated only after careful designing of the fluidized bed reactor, the bed height, the distribution of bubbles, and the particle size of the catalyst. ${ }^{34), 40)}$

After the problem of forces had been overcome, a number of operations totalling about 2,400 hours 


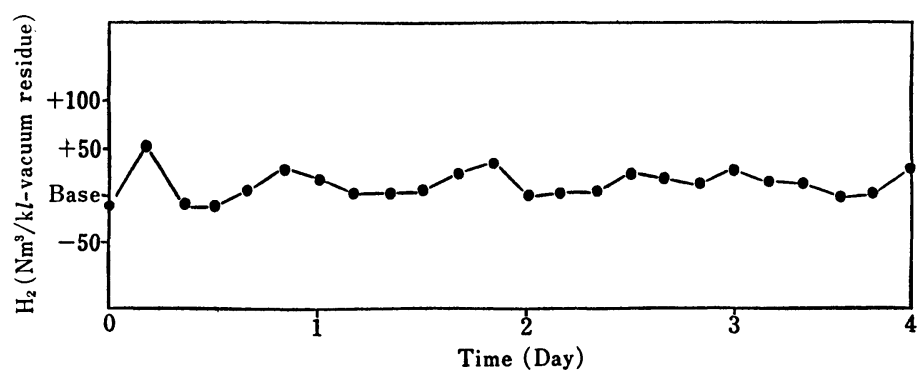

Fig. 11 Amount of Hydrogen Generated in Cracker

Table 5 Product Yield Obtained with Large Scale Pilot Plant

\begin{tabular}{|c|c|}
\hline $\begin{array}{l}\text { Feedstock: Arabian light vacuum residue } \\
\text { Specific gravity }\left(15 / 4^{\circ} \mathrm{C}\right) \\
\text { Viscosity at } 120^{\circ} \mathrm{C}(\mathrm{cSt}) \\
\text { Sulfur (wt } \%) \\
\text { Conradson carbon residue (wt } \%)\end{array}$ & $\begin{array}{r}1.021 \\
410 \\
4.2 \\
21.6\end{array}$ \\
\hline $\begin{array}{l}\text { Reaction conditions: } \\
\text { Cracking temperature }\left({ }^{\circ} \mathbf{C}\right) \\
\text { Regeneration Temperature }\left({ }^{\circ} \mathrm{C}\right) \\
\text { Roasting temperature }\left({ }^{\circ} \mathrm{C}\right) \\
\text { Pressure }\left(\mathrm{kg} / \mathrm{cm}^{2}\right)\end{array}$ & $\begin{array}{l}514 \\
830 \\
750 \\
2.0\end{array}$ \\
\hline $\begin{array}{l}\text { Yield }(\text { vol\%): } \\
\mathrm{C}_{2-} \\
\mathrm{C}_{3} \\
\mathrm{C}_{4} \\
\mathrm{C}_{5}-180^{\circ} \mathrm{C} \\
180-230^{\circ} \mathrm{C} \\
230-360^{\circ} \mathrm{C} \\
360-510^{\circ} \mathrm{C} \\
\text { total }\end{array}$ & $\begin{array}{r}9.0^{*} \\
15.2 \\
2.4 \\
5.2 \\
8.2 \\
14.2 \\
28.2 \\
82.4\end{array}$ \\
\hline
\end{tabular}

Hydrogen $\left(\mathrm{Nm}^{3} / \mathrm{k} l\right.$-feed $) \quad 185$

Note: * Fuel oil equivalent

Table 6 Properties of Cracked Oil Before and After Hydrotreating

\begin{tabular}{lcc}
\hline Kerosene: & \multicolumn{2}{c}{ cracked oil } \\
& before & after \\
Reaction & neutral & neutral \\
Flash point $\left({ }^{\circ} \mathrm{C}\right)$ & 63 & 61 \\
$95 \%$ Fraction $\left({ }^{\circ} \mathrm{C}\right)$ & 259.5 & 261.5 \\
Sulfur (wt\%) & 1.85 & 0.0093 \\
Smoke point (mm) & 14 & 21 \\
Copper corrosion & 1 & $1 \mathrm{a}$ \\
Color & - & - \\
\hline Diesel oil: & \multicolumn{3}{c}{} \\
& cracked oil \\
Reaction & before & after \\
Flash point $\left({ }^{\circ} \mathrm{C}\right)$ & neutral & neutral \\
$90 \%$ Fraction $\left({ }^{\circ} \mathrm{C}\right)$ & 126 & 97 \\
Pour point $\left({ }^{\circ} \mathrm{C}\right)$ & 320.5 & 319.5 \\
Cetane no. & -15.0 & -10.0 \\
Cetane index & - & - \\
Viscosity at $30^{\circ} \mathrm{C}(\mathrm{cSt})$ & 39.1 & 51.0 \\
Sulfur (wt $\%)$ & 5.55 & 4.93 \\
& 3.63 & 0.63 \\
\hline
\end{tabular}

were conducted. Typical test results are shown in Tables 5 and 6.44) Figure 11 illustrates the amount of hydrogen generated in the cracker. The large-scale-pilot plant showed excellent stability.
Efforts to improve catalyst activity were made also in the plant; and hydrogen generation amounting to about $185 \mathrm{Nm}^{3} / \mathrm{k} l$-feed oil was estimated. It was found that a large amount of hydrogen could be generated from the process without coke production and that the amount of hydrogen generated was sufficient to desulfurize the product distillates.

Concentrations of $\mathrm{SO}_{x}$ and $\mathrm{NO}_{x}$ were below 100 ppm and $20 \mathrm{ppm}$, respectively. It was also noted that flue gas from the process contained such small amounts of $\mathrm{SO}_{x}$ and $\mathrm{NO}_{x}$ that, even without desulfurization and/or denitrogenation, it caused no pollution problems.

\section{Acknowledgements}

The author wishes to express his thanks to the Research Association for Residual Oil Processing for its financial support. $\mathrm{He}$ also extends his gratitude to Dr. Hiromi Ozaki, General Manager of the New Project Department of Nippon Mining Co. Petroleum Division, Mr. Tadashi Murakami, Managing Director of Sanyo Petroleum Chemistry Co., and co-authors whose names appear in the references.

\section{References}

1) Shibata, K., Kiyoura, T., Bull. Chem. Soc. Japan, 42, 871 (1969).

2) Walker, Jr., P. L., Shelef, M., Anderson, R. A., "Chemistry and Physics of Carbon", vol. 4, p. 324 (1968).

3) Morita, J., Ikezoe, M., Hashimoto, T., Sato, S., J. Fuel Soc. Japan, 61, (657), 42 (1982).

4) Fujimoto, K., Yuki Gosei Kagaku, 41, (6), 532 (1983).

5) Ozaki, A., Sekiyu Gakkaishi, 19, 910 (1976).

6) Fujimoto, K., Kagaku Kogyo, (11), 1150 (1976).

7) Ozaki, H., Satomi, Y., Suzuka, T., Miyake, T., Yamane, M., Yata, N., Sekiyu Gakkaishi, 18, 395 (1975).

8) Suzuka, T., Ozaki, H., Sekiyu Gakkaishi, 25, (4), 235 (1982).

9) Yoshioka, S., Miyamoto, T., Hirato, M., Satomi, Y., Suzuka, T., Ozaki, H., Sekiyu Gakkaishi, 23, (5), 355 (1980).

10) Murakami, T., Hirato, M., Power, (144), 90 (1978).

11) Suzuka, T., Inoue, Y., Aizawa, S., Ozaki, H., Nippon Kagaku Kaishi, 1980, (6), 1020. 
12) Uemaki, O., Fujikawa, M., Kugo, M., Nippon Kagaku Kaishi, 1980, (6), 1012.

13) Mori, K., Morimitsu, T., Ijiri, R., PETROTECH, 8, (5), 405 (1985).

14) Suzuka, T., Ozaki, H., Sekiyu Gakkaishi, 25, (4), 228 (1982).

15) Suzuka, T., Fukase, S., Yamane, M., Ozaki, H., 25 th Meeting of Japan Petrol. Inst., Osaka, 1983.

16) Suzuka, T., Inoue, Y., Aizawa, S., Ozaki, H., Sekiyu Gakkaishi, 26, (3), 174 (1983).

17) Tarman, P. B., 8th Synthetic Pipeline Gas Symposium, Chicago, 1976.

18) Nakaguchi, S., Sekiyu Gakkaishi, 20, (1), 69 (1977).

19) Okura, A., Tokuda, M., Matsushita, Y., Tetsu to Hagane, 48, (9), 1039 (1962).

20) Sakuraya, K., Kitahara, Y., Morinaka, I., Kamiya, K., Ozawa, M., Tanaka, M., Tetsu to Hagane, 65, (2), 176 (1979).

21) Nippon Tekkou Kyokai, "Tekkou Binran", Maruzen, vol. 2, p. 127 (1981)

22) Suzuka, T., Inoue, Y., Aizawa, S., Ozaki, H., Sekiyu Gakkaishi, 26, (3), 181 (1983).

23) Bolsaitis, P., Nagata, K., Metallurgical Transactions B, 11B, 185 (1980)

24) McCormick, S., Dayananda, M. A., Grace, R. E., Metallurgical Transactions B, 6B, 55 (1975).

25) Ozawa, A., Ohkura, T., Sulfuric Acid and Industry, 32, (11), 243 (1979).

26) Suzuka, T., Ishibashi, Y., Yoshioka, S., Ohse, H., Murakami, T., Ozaki, H., Sekiyu Gakkaishi, 26, (3), 188 (1983).

27) Ozaki, H., Murakami, T., Suzuka, T., Yoshioka, S., Ohse, H., ACS Seattle Meeting, March 20-25, 1983.
28) Yazawa, A., Sulfuric Acid and Industry, 23, (10), 277 (1970).

29) Yagi, S., Kunii, D., Kogyo Kagaku Zasshi, 66, 133 (1953).

30) Hisajima, I., Kondo, Y., J. Mining and Metallurgical Inst. Japan, 68, 319 (1952).

31) Shen, C. Y., Johnstone, H. F., A.I.Ch.E. Journal, 1, (3), 348 (1955)

32) Mathis, J. F., Watson, C. C., A.I.Ch.E. Journal, 2, (4), 518 (1956).

33) Frye, C. G., Lake, W. C., Eckstrom, H. G., A.I.Ch.E. Journal, 4, (4), 403 (1958).

34) Yoshioka, S., Kansai Meeting of Chem. Eng. Soc. Japan, Osaka, Dec. 5-6, 1985.

35) Yoshioka, S., 17 th Autumn Meeting of Chem. Eng. Soc. Japan, Sendai, Sept. 29-Oct. 1, 1983.

36) Kunii, D., Levenspiel, O., "Fluidization Engineering", John Wiley \& Sons Inc.

37) Morooka, N., "Ryudoso Kogaku", Kagaku Kogaku Kyokai, p. 40 (1981).

38) Murakami, T., Shinshuu Meeting of Chem. Eng. Soc. Japan, Ueda, July 18-19, 1983.

39) Ozaki, H., Murakami, T., Suzuka, T., Yoshioka, S., Ohse, H., 32 nd Canadian Chem. Eng. Conf., Vancouver, B. C., Canada, Oct. 3-6, 1982.

40) Ishibashi, Y., Matsuda, K., Nakaura, H., Murakami, T., Kemikaru Enginiaringu, (5), 60 (1984).

41) Hosney, N., Grace, J. R., 4 th Int. Conf. on Fluidization, Kashikojima, Japan, May 29-June 3, 1983.

42) Kennedy, T. C., Donovan, J. E., Trigas, A., A.I.Ch.E. Journal, 27, (3), 351 (1981).

43) Geldart, D., Powder Technol., 7, 285 (1973); 19, 133 (1978).

44) Kato, K., Energy and Resources, 4, (2), 127 (1983). 


\author{
水素発生を伴う重質油分解 \\ 鈴 鹿 輝 男 \\ 日本鉱業(株) 総合研究所, 335 埼玉県戸田市新曾南 3-17-35
}

重質油分解プロセスに执いては副生するコークの処理方法が 問題となるが, 本研究は酸化鉄の酸化還元を利用して副生コ一 クとスチームから水素を発生させる工程を加味した重質油分解 プロセスの開発について検討したものであり，その主な成果は 次のとおりである。

触媒としてラテライト鉱石を用いて減圧残油の分解を行い， 触媒上にコークを付着させた後，このコークを $850^{\circ} \mathrm{C}$ で部分 酸化すると，触媒中に含まれる四三酸化鉄 $\left(\mathrm{Fe}_{3} \mathrm{O}_{4}\right)$ が還元さ れて酸化第一鉄 $(\mathrm{FeO})$ に変化した。還元された酸化鉄にスチ 一ムを接触させると水素を発生し, 酸化第一鉄は四三酸化鉄に 酸化されることがわかった（Fig. 5)。また，酸化鉄の還元率 および再生塔における発熱量は送入酸素と触媒上ュークの比 $\left(\mathrm{O}_{2} / \mathrm{C}\right)$ により制御できることがわかった（Fig. 4)。

Fig. 6 は本プロセスにおける硫黄の挙動を概念的に表した ものである。分解反応後の触媒を再生塔で部分酸化反応に供す るとコーク中の硫黄分がガス化し, 即座に触媒中に FeS とし て捕捉されるが，生成した $\mathrm{FeS}$ は水素発生塔でスチームによ り脱硫される。，そのため再生塔廃ガス中の硫黄分は $100 \mathrm{ppm}$ 以下となる。また，空気比が低いため $\mathrm{NO}_{x}$ の発生は見られな い。

大慶の減圧残油あるいは脱硫した残油のように硫黄分の低い 原料の場合はこの方式でる触媒中の硫黄分はバランスするが, 中東系の減圧残油を脱硫せずにフィードする場合は, 触媒中に 硫黄分が蓄積することがある。

高硫黄原料油を処理するときの反応は以下のようになる。

分解塔において, $3 \mathrm{FeO}+\mathrm{H}_{2} \mathrm{O} \rightarrow \mathrm{Fe}_{3} \mathrm{O}_{4}+\mathrm{H}_{2}$
$\mathrm{FeO}+\mathrm{Feed} \rightarrow \mathrm{Coke} / \mathrm{Fe}_{3} \mathrm{O}_{4}+\mathrm{Oil}+\mathrm{Gas}$

再生塔において,

Coke $/ \mathrm{Fe}_{3} \mathrm{O}_{4}+\mathrm{O}_{2} \rightarrow 3 \mathrm{FeO}+\mathrm{CO}+\mathrm{CO}_{2}+\mathrm{SO}_{2}$

$\mathrm{Fe}_{3} \mathrm{O}_{4}+\mathrm{CO} \rightarrow 3 \mathrm{FeO}+\mathrm{CO}_{2}$

$\mathrm{FeO}+\mathrm{SO}_{2}+3 \mathrm{CO} \rightarrow \mathrm{FeS}+3 \mathrm{CO}_{2}$

ばい焼塔において,

$3 \mathrm{FeS}+5 \mathrm{O}_{2} \rightarrow \mathrm{Fe}_{3} \mathrm{O}_{4}+3 \mathrm{SO}_{2}$

このプロセスの工業化について検討するため, 0.6 BPD の 3 塔循環流動層パイロットプラントの運転を行った。運転条 件を Table 2 に, 使用した触媒の性状を Table 3 に示す。 Fig. 7 の 10 日間の連続運転状況 結果から, 再生塔の CO/ $\mathrm{CO}_{2}$ 比が高いほど水素発生量が多いこと, 約 $200 \mathrm{~N} / / \mathrm{kg}$-feed oil の水素がこのプロセスで得られることがわかった。コーク 存在下で硫化鉄のばい焼を行うと，炭素より硫黄の方が酸化さ れやすいことが見出された。

1981 年に 250 BPD の大型パイロットプラント (Fig. 10) を日本鉱業(株) 水自製油所飞建設し, 総計約 2,400 時間の運 転を行い, 1983 年にその運転を終了した。運転当初は流動層 内の推力発生等のトラブルを経験したが, 流動層の設計, 流動 層高, 気泡径, 粒子径等の改良により解決した。水素化精製前 後の生成油性状例を Tables 5 と 6 亿, 水素発生状況を Fig. 11 に示す。水素発生量約 $185 \mathrm{Nm}^{3} / \mathrm{k} l$-feed oil が得られる見 通しを得たが，これはこのプロセスで得られる留出油を水素化 精製するに十分な量である。再生塔廃 ガス中の $\mathrm{SO}_{x}$ および $\mathrm{NO}_{x}$ 濃度は，それぞれ $100 \mathrm{ppm}$ および $20 \mathrm{ppm}$ 以下であり, 脱硫設備なしでも無公害であることが判明した。

\title{
Keywords
}

Cracking, Fluidized bed, Hydrogen generation, Iron oxide, Laterite, Residual oil 